\begin{tabular}{|l|l|l|}
\hline \multicolumn{2}{|c|}{ PublisherInfo } \\
\hline \hline PublisherName & $:$ & BioMed Central \\
\hline \hline PublisherLocation & $:$ & London \\
\hline \hline PublisherImprintName & $:$ & BioMed Central \\
\hline \hline
\end{tabular}

\title{
MODY-fying gene expression in diabetes
}

\begin{tabular}{|l|l|l||}
\hline \multicolumn{2}{|c|}{ ArticleInfo } \\
\hline \hline ArticleID & $:$ & 3762 \\
\hline \hline ArticleDOI & $:$ & $10.1186 /$ gb-spotlight-20000912-01 \\
\hline \hline ArticleCitationID & $:$ & spotlight-20000912-01 \\
\hline \hline ArticleSequenceNumber & $:$ & 199 \\
\hline \hline ArticleCategory & $:$ & Research news \\
\hline \hline ArticleFirstPage & $:$ & 1 \\
\hline \hline ArticleLastPage & $:$ & 2 \\
\hline \hline & & RegistrationDate : 2000-09-12 \\
ArticleHistory & $:$ & OnlineDate \\
\hline \hline ArticleCopyright & $:$ & BioMed Central Ltd2000-09-12 \\
\hline \hline ArticleGrants & $:$ & \\
\hline \hline ArticleContext & $:$ & 130591111 \\
\hline \hline
\end{tabular}




\section{Jonathan B Weitzman}

Email: JWeitzman@elabseurope.com

HNF1 $\alpha$ (hepatocyte nuclear factor 1) was originally isolated as a liver transcription factor. So it came as a sweet surprise to researchers when HNF1 $\alpha$ was identified as the gene mutated in patients suffering from MODY3, maturity onset diabetes of the young subtype 3. As they report in the 15 August EMBO Journal Wang et al. (EMBO Journal 2000, 19:4257-4264) used a tetracyclin-regulated system to identify genes controlled by HNF1 $\alpha$. They expressed the most common diabetes-associated mutant form of HNF1 $\alpha$ (P291fsinsC) in the INS-1 insulinoma cell line. This mutant form reduced the expression of several genes important for pancreatic $\beta$-cell function and inhibited expression of the insulin gene. Other genes suppressed by HNF1 $\alpha$ include those involved in glucose transport (GLUT2) and glycolysis (e.g. encoding proteins aldolase B and L-pyruvate kinase). These inhibitory effects result in reduced cellular insulin, insulin secretion and ATP production.

\section{References}

1. Mutations in the hepatocyte nuclear factor-1alpha gene in maturity-onset diabetes of the young.

2. EMBO Journal, [http://www.emboj.org/]

3. Transcriptional activation by tetracyclines in mammalian cells. 